\title{
Remote sensing improves prediction of tropical montane species diversity but performance differs among taxa
}

\author{
Christine I.B. Wallis ${ }^{\mathrm{a}, \mathrm{b}, *}$, Gunnar Brehm ${ }^{\mathrm{c}}$, David A. Donoso ${ }^{\mathrm{d}, 1}$, Konrad Fiedler $^{\mathrm{e}}$, \\ Jürgen Homeier ${ }^{\mathrm{f}}$, Detlev Paulsch ${ }^{\mathrm{g}}$, Dirk Süßenbach ${ }^{\mathrm{h}}$, Yvonne Tiede ${ }^{\mathrm{a}}$, Roland Brandl ${ }^{\mathrm{i}}$, \\ Nina Farwig ${ }^{\mathrm{a}}$, Jörg Bendix ${ }^{\mathrm{b}}$ \\ a Conservation Ecology, Faculty of Biology, Philipps-Universität Marburg, Karl-von-Frisch-Straße 8, 35043 Marburg, Germany \\ ${ }^{\mathrm{b}}$ Laboratory for Climatology and Remote Sensing, Faculty of Geography, Philipps-Universität Marburg, Deutschhausstraße 12, 35032 Marburg, Germany \\ ${ }^{\mathrm{c}}$ Institut für Spezielle Zoologie und Evolutionsbiologie mit Phyletischem Museum, Friedrich-Schiller-Universität Jena, Erbertstraße 1, 07743 Jena, Germany \\ d Museo de Colecciones Biológicas (MUTPL), Universidad Técnica Particular de Loja, San Cayetano Alto s/n, Loja, Ecuador \\ e Department of Botany and Biodiversity Research, University of Vienna, Rennweg 14, 1030 Wien, Austria \\ ${ }^{f}$ Plant Ecology, Albrecht von Haller Institute for Plant Sciences, University of Göttingen, Untere Karspüle 2, 37073 Göttingen, Germany \\ ${ }^{\mathrm{g}}$ Gesellschaft für angewandte Ökologie und Umweltplanung mbH, Impexstraße 5, 69190 Walldorf, Germany

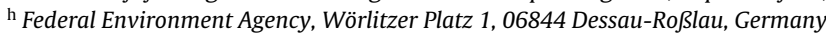 \\ ${ }^{i}$ Animal Ecology, Department of Ecology, Faculty of Biology, Philipps-Universität Marburg, Karl-von-Frisch-Straße 8, 35043 Marburg, Germany
}

\section{A R T I C L E I N F O}

\section{Article history:}

Received 9 June 2016

Received in revised form 18 January 2017

Accepted 21 January 2017

Available online 27 March 2017

\section{Keywords:}

Ants

Birds

Gray-level co-occurrence matrix

Image textures

Moths

Orthophotos

Partial least-squares regression

Species turnover

Trees

Tropical mountain rainforest

\begin{abstract}
A B S T R A C T
Texture information from passive remote sensing images provides surrogates for habitat structure, which is relevant for modeling biodiversity across space and time and for developing effective ecological indicators. However, the applicability of this information might differ among taxa and diversity measures. We compared the ability of indicators developed from texture analysis of remotely sensed images to predict species richness and species turnover of six taxa (trees, pyraloid moths, geometrid moths, arctiinae moths, ants, and birds) in a megadiverse Andean mountain rainforest ecosystem. Partial least-squares regression models were fitted using 12 predictors that characterize the habitat and included three topographical metrics derived from a high-resolution digital elevation model and nine texture metrics derived from very high-resolution multi-spectral orthophotos. We calculated image textures derived from mean, correlation, and entropy statistics within a relatively broad moving window $(102 \mathrm{~m} \times 102 \mathrm{~m})$ of the near infra-red band and two vegetation indices. The model performances of species richness were taxon dependent, with the lowest predictive power for arctiinae moths (4\%) and the highest for ants (78\%). Topographical metrics sufficiently modeled species richness of pyraloid moths and ants, while models for species richness of trees, geometrid moths, and birds benefited from texture metrics. When more complexity was added to the model such as additional texture statistics calculated from a smaller moving window $(18 \mathrm{~m} \times 18 \mathrm{~m})$, the predictive power for trees and birds increased significantly from $12 \%$ to $22 \%$ and $13 \%$ to $27 \%$, respectively. Gradients of species turnover, assessed by non-metric two-dimensional scaling (NMDS) of Bray-Curtis dissimilarities, allowed the construction of models with far higher predictability than species richness across all taxonomic groups, with predictability for the first response variable of species turnover ranging from $64 \%$ (birds) to $98 \%$ (trees) of the explained change in species composition, and predictability for the second response variable of species turnover ranging from $33 \%$ (trees) to 74\% (pyraloid moths). The two NMDS axes effectively separated compositional change along the elevational gradient, explained by a combination of elevation and texture metrics, from more subtle, local changes in habitat structure surrogated by varying combinations of texture metrics. The application of indicators arising from texture analysis of remote sensing images differed among taxa and diversity
\end{abstract}

\footnotetext{
* Corresponding author.

E-mail addresses: christine.wallis@staff.uni-marburg.de (C.I.B. Wallis), gunnar.brehm@uni-jena.de (G. Brehm), david.donosov@gmail.com (D.A. Donoso), konrad.fiedler@univie.ac.at (K. Fiedler), jhomeie@gwdg.de (J. Homeier),d.paulsch@gefaoe.de (D. Paulsch), dirk.suessenbach@web.de (D. Süßenbach), yvonne.tiede@biologie.uni-marburg.de (Y. Tiede), brandlr@biologie.uni-marburg.de (R. Brandl), nina.farwig@biologie.uni-marburg.de (N. Farwig), bendix@geo.uni-marburg.de (J. Bendix).

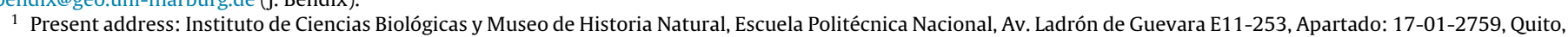
Ecuador.
} 
measures. However, these habitat indicators improved predictions of species diversity measures of most taxa, and therefore, we highly recommend their use in biodiversity research.

(C) 2017 Elsevier Ltd. All rights reserved.

\section{Introduction}

Information derived from remote sensing (RS) provides costeffective proxies for primary productivity and habitat structure (Rocchini et al., 2016, 2015; Wang et al., 2010). Species occurrence of individual species and species diversity are often correlated to these proxies (Cintra and Naka, 2012; Couteron et al., 2005; Estes et al., 2010; Goetz et al., 2007; Mairota et al., 2015; Rocchini et al., 2010; Tews et al., 2004). Therefore, RS provides useful information for models of ecological variables across large extents with a high spatial resolution. Such spatially-explicit models are of considerable importance in conservation planning if recurrent RS information is available as they provide maps and offer effective indicator systems for area-wide monitoring. However, the success of these models varies considerably among taxa and modeled variables of biodiversity. A deeper understanding of this variation in predictability of diversity measures would be helpful for planning and establishing monitoring systems for documenting environmental change, especially in biota where biodiversity inventories are difficult to achieve.

Particularly the use of RS texture metrics has strengthened statistical models of biodiversity (Culbert et al., 2012; Estes et al., 2010; Wallis et al., 2016b; Wood et al., 2013). In textural approaches, a new value is assigned to each pixel and characterizes the distribution of spectral values in a particular neighborhood, which is defined by a moving or fixed window (Haralick, 1979). Depending on the considered textural feature, which ranges from simple metrics (e.g., mean, variance) to complex metrics (e.g., contrast, correlation), such variables characterize different spatial aspects of habitat structure (e.g., habitat heterogeneity). For example, image textures based on very high-resolution optical imagery successfully predict and map the structure of forests (Wood et al., 2012) and distributional patterns of bird diversity (St-Louis et al., 2014). Models of a montane forest in southwestern Colorado that include texture metrics from RS are more strongly correlated with biomass than models using topographical or spectral metrics (Kelsey and Neff, 2014). Similar results have been obtained for mature biomass in a moist tropical forest (Lu and Batistella, 2005). Therefore, textural information from RS images might address the relationship between environment and biodiversity more effectively than raw spectral bands or common vegetation indices.

Tropical mountain rainforests, particularly Andean rainforests, are among the most diverse and threatened biodiversity hotspots of the world (e.g., Brehm et al., 2016; Tapia-Armijos et al., 2015). Studies of similarly diverse systems have investigated elevation and topography as predictors of biodiversity, and have successfully modeled the occurrence of certain tree species and species richness of moths and ants (e.g., Kübler et al., 2016; Malsch et al., 2008; Nakamura et al., 2015). However, the results are highly taxon dependent, and some taxa are difficult to predict from simple environmental variables (Fiedler et al., 2008; Tiede et al., 2016a). Thus, models of tropical diversity would benefit from the inclusion of structural habitat information.

A great challenge in tropical diverse systems is the assembly of meaningful biodiversity data. The extraordinary high species richness and the low availability of taxonomic and ecological information for most of the species forces ecological studies in tropical rainforest ecosystems to target well-known taxa, e.g., woody plants
(Homeier et al., 2010), or taxa such as ants or birds that occupy different trophic levels within the food webs (Gerlach et al., 2013; Kati et al., 2004; Schuldt et al., 2014; Sekercioğlu et al., 2016; Tiede et al., 2017; Donoso and Ramón, 2009).

Most RS-based diversity research has focused on measures of alpha-diversity and has ignored community structure. Changes in species composition along environmental gradients are measured by a variety of metrics of species turnover, ranging from dissimilarity measures to scores along ordination axes (Socolar et al., 2016; Whittaker, 1972; Brehm and Fiedler, 2004). Various studies have shown that the composition of species usually provides detailed information on habitat characteristics (Banks-Leite and Cintra, 2008; Cintra and Naka, 2012; Farwig et al., 2014; Müller et al., 2009; Thiollay, 1994). RS-based habitat indicators might improve predictions of species turnover as spectral distances are, for example, strongly correlated to patterns of floristic species composition among sites in Ecuadorian Amazonia (Tuomisto et al., 2003). Unfortunately, the computation of spectral distances and species similarities among sites and the mapping of distance-based species turnover is time consuming because the number of spectral distances increases with the square of the number of sampled sites (Rocchini et al., 2016). A number of studies, therefore, have assessed species turnover using ordination techniques (Farwig et al., 2014; Feilhauer and Schmidtlein, 2009; Gu et al., 2015; Muenchow et al., 2013; Wallis et al., 2016b). For instance, Feilhauer and Schmidtlein (2009) performed a detrended correspondence analysis to identify different gradients in the composition of vegetation. Scores of sites along the ordination axes that represent these environmental gradients were regressed against topographical and spectral metrics calculated for the sites. Ordination techniques, therefore, might be the superior choice to assess species turnover when RS information are used to produce continuous maps of environmental gradients, e.g., the compositional change of bird species along habitat structure (Wallis et al., 2016b).

Here, we investigated models that consider species richness and ordinations of compositional change using non-metric multidimensional scaling (NMDS) as a measure of species turnover of trees, moths (Pyraloidea, Geometridae, Arctiinae), ants, and birds in a tropical mountain rainforest ecosystem. We fitted partial leastsquares regressions for all taxa and diversity measures separately by assessing topographical metrics derived from a digital elevation model and image texture metrics derived from an airborne multi-spectral sensor. Our aim was to compare the predictability of species richness and species turnover across the six taxa. We identified differences among the selected taxonomic groups and examined which combination of habitat indicators served well for each taxonomic group as well as for the selected diversity measure. Our findings provide guidelines for the development of a RS-based indicator system for monitoring biodiversity in response to environmental changes in complex tropical forests.

\section{Methods}

\subsection{Study area}

The study area is located in southeastern Ecuador, an area known for its high climatic and environmental heterogeneity and high levels of species richness with numerous endemic taxa (Bendix 


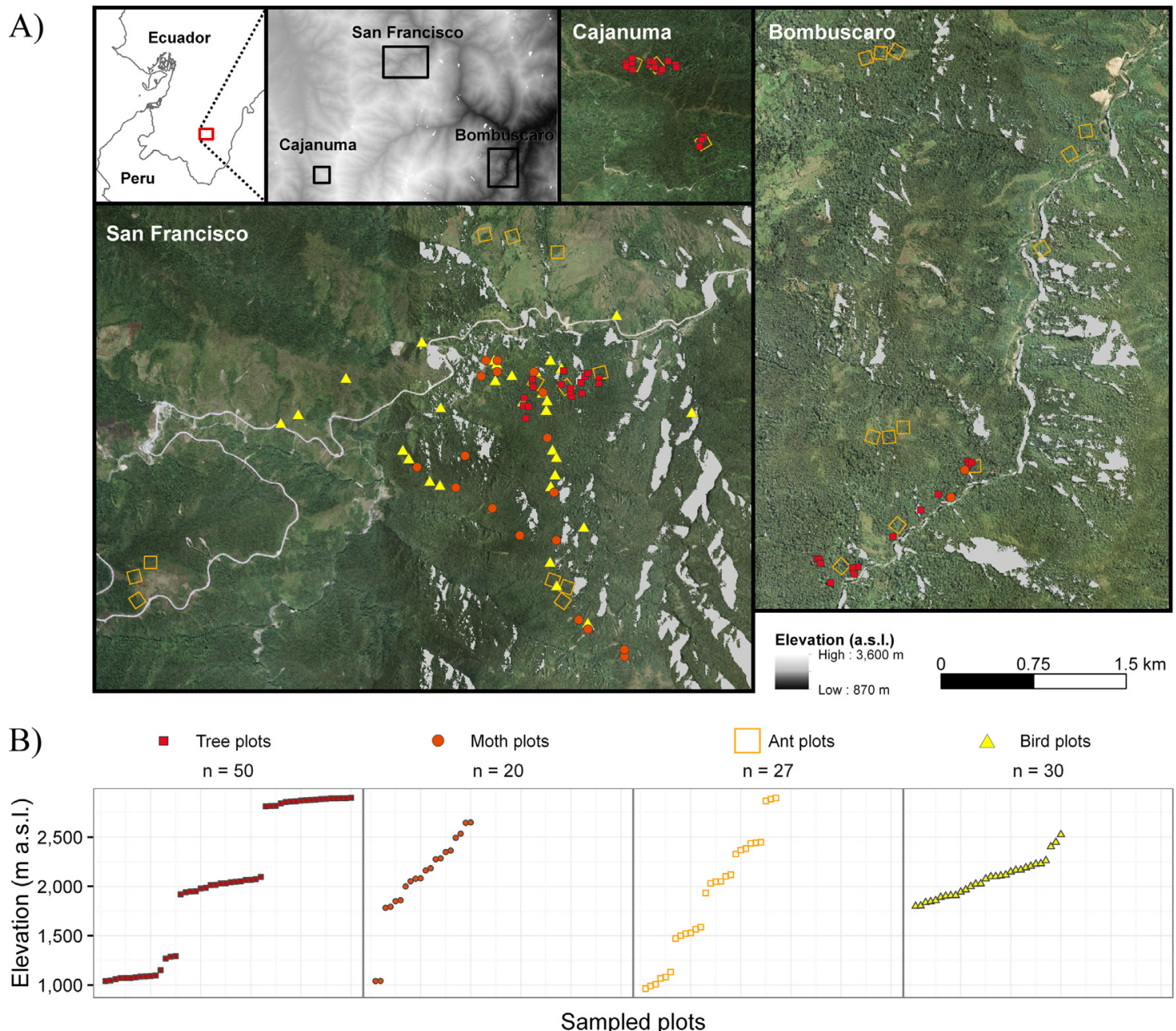

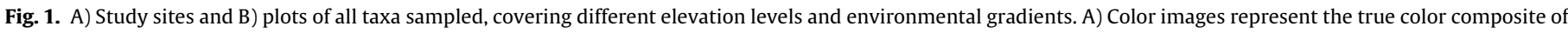

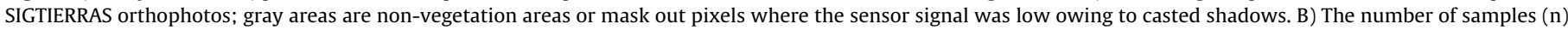
stratified along the elevational gradient for each taxon.

and Beck, 2016; Brehm et al., 2016, 2008; Tapia-Armijos et al., 2015; Werner and Homeier, 2015; Fig. 1). The climate is humid throughout the year, with mean annual precipitation between $2200 \mathrm{~mm}$ at elevations of $\sim 1000 \mathrm{~m}$ a.s.l. and $4500 \mathrm{~mm}$ at $\sim 3000 \mathrm{~m}$ a.s.l. Mean annual air temperature decreases from $20^{\circ} \mathrm{C}$ at $\sim 1000 \mathrm{~m}$ a.s.l., to $15.5^{\circ} \mathrm{C}$ at $\sim 2000 \mathrm{~m}$ a.s.l., to $9.5^{\circ} \mathrm{C}$ at $\sim 3000 \mathrm{~m}$ a.s.l. (Beck et al., 2008; Bendix et al., 2008). Precipitation peaks from June to August, and the period from December to February is relatively dry (Beck and Kottke, 2008; Bendix et al., 2006).

Topographical complexity, heterogeneity of climate regimes along the elevational gradient, and anthropogenic disturbances have formed various forest types: evergreen premontane forest ( $\leq 1300 \mathrm{~m}$ a.s.l., Bombuscaro site), evergreen lower montane forest (between 1300 and $2100 \mathrm{~m}$ a.s.l., San Francisco site), and evergreen upper montane forest (>2100 $\mathrm{m}$ a.s.l., San Francisco and Cajanuma sites), with characteristic subtypes along valleys, ravines, ridges, and anthropogenic replacement systems (Homeier et al., 2008). These forest types differ in species richness, floristic composition, and structural characteristics, e.g., canopy height decreases with elevation. We focused on taxonomic groups sampled on different forest plots and elevations in the Reserva Biológica San Francisco, or additionally at Bombuscaro and Cajanuma which are parts of the Podocarpus National Park (Fig. 1; Table 1). Outside the protected lands in the study area, the forest has been mostly converted during the last few decades to pastures or further degraded to bracken- infested areas (Curatola Fernández et al., 2015; Tapia-Armijos et al., 2015).

\subsection{Sampling of taxa}

All woody plants (including palms and arborescent ferns) with a diameter at breast height $(\mathrm{dbh}) \geq 5 \mathrm{~cm}$ and a height $\geq 1.3 \mathrm{~m}$ were sampled on 50 permanent plots each covering $20 \mathrm{~m} \times 20 \mathrm{~m}$ between 2007 and 2008 (Wallis and Homeier, 2017). GPS points were taken in the middle of each plot. All plots were located in mature forest without visible human disturbance. Tree individuals were identified to the species or morphospecies level when possible.

Nocturnal moths were sampled on 20 plots during three periods between 1999 and 2000 using light traps equipped with two backlight $15 \mathrm{~W}$ tubes operated between 18:30 and 21:30 local time (UTC-5:00; Brehm, 2002; Brehm and Fiedler, 2010; Suessenbach, 2003; Suessenbach and Fiedler, 2010a, 2010b). Catches were restricted to periods from three days after full moon until five days before full moon. Specimens were sorted to morphospecies within three diverse taxa: geometrid moths (Geometridae), pyraloid moths (Pyraloidea), and arctiinae moths (Erebidae: Arctiinae). Previous analyses of the same samples have shown that these taxa differ in diversity patterns, body size, host plant affiliations, and other traits (Fiedler et al., 2008). To account for such differences, we 
Table 1

Summary of basic information on sampling of the investigated taxonomic groups. See also Fig. 1.

\begin{tabular}{|c|c|c|c|c|c|}
\hline Taxonomic group & Year & Method & Total no. of species & Min. no. of species per site & Max. no. of species per site \\
\hline Trees & 2007, 2008 & Counts on $20 \mathrm{~m} \times 20 \mathrm{~m}$ plots & 443 & 12 & 41 \\
\hline Geometridae & 1999,2000 & Light traps & 1223 & 135 & 296 \\
\hline Pyraloidea & 1999, 2000 & Light traps & 753 & 62 & 315 \\
\hline Arctiinae & 1999, 2000 & Light traps & 443 & 34 & 149 \\
\hline Ants & 2014 & Nutrient baits & 88 & 1 & 25 \\
\hline Birds & $2000,2001,2002$ & Point counts (30 min) & 147 & 14 & 46 \\
\hline
\end{tabular}

treated these taxa separately to compare the predictability of biodiversity patterns among putatively rather homogeneous groups of insects.

Ants (Formicidae) were sampled on 27 plots in two seasons in 2014 using a rapid assessment method with nutrient baits following Peters et al. (2014) and described in detail in Tiede et al. (2017; Wallis et al., 2016a). In short, we exposed six different nutrient baits $\left[\mathrm{H}_{2} \mathrm{O}, \mathrm{NaCl}, \mathrm{CHO}\right.$ (sucrose), protein (glutamine), $\mathrm{CHO}$-protein mix, and lipids (olive oil)] in the wet and the dry seasons. The ant fauna of Ecuador consists of species that are taxonomically poorly defined (Salazar et al., 2015). Therefore, we built a COI (mitochondrial cytochrome c oxidase I) barcode reference library that aided us to refine our morphology-based identification framework (Tiede et al., 2016b; see also Domínguez et al., 2016; Tiede et al., 2017). For analysis, ant species collected in the two seasons were pooled.

Bird species occurrence was assessed on 30 plots in the study area under favorable weather conditions at 6:00-10:00 and 16:00-18:00 (UTC-5:00) between 2000 and 2002 (Paulsch and Müller-Hohenstein, 2008; Paulsch and Wallis, 2016). Standardized point counts $(30 \mathrm{~min}$ ) were repeated 12 times on each plot and combined with mist-netting data to comprehensively assess bird assemblages.

\subsection{Diversity measures}

For each taxon, we calculated species richness and aspects of species turnover with the following considerations. In species-rich communities, the number of species recorded in a sample depends on the number of sampled individuals (Colwell et al., 2012). The number of moth individuals attracted to light traps, for example, depends on light conditions and temperature (Beck et al., 2011). In the study area, the number of tree individuals varied considerably across plots, which led to a bias in observed species numbers. Thus, we estimated species richness for trees and all moth taxa at a coverage of $70 \%$ of the expected total species richness using rarefaction and extrapolation as recommended by Colwell et al. (2012) using the function estimateD in the R package iNext (Hsieh et al., 2016; R Core Team, 2016; for statistics, see Table 1 in Appendix A).

We characterized the change in species composition (betadiversity) across plots for each taxon using ordination. For each taxon, we calculated pair-wise Bray-Curtis dissimilarities using presence/absence data between all plots for which a species list of the respective taxon was available. Subsequently, we performed NMDS using the $\mathrm{R}$ function metaMDS in vegan. The stress value for two-dimensional ordinations of all taxa was $<0.2$ (Table 2 in Appendix A), which indicates an appropriate NMDS solution. We extracted the site scores for the two dimensions. Both dimensions (NMDS I and NMDS II) are a numerical measure of the compositional change in the community across all plots.

\subsection{Preprocessing of multi-spectral orthophotos}

Within the framework of the Ecuadorian program "National System of Information on Rural Lands and Technological Infrastructure", a digital elevation model (DEM) with a spatial resolution of $3 \mathrm{~m}$ and ortho-rectified images with a resolution of $0.3 \mathrm{~m}$ and
Table 2

Topographical metrics used in addition to texture metrics to fit models which predict diversity of sampled taxa.

\begin{tabular}{lll}
\hline $\begin{array}{l}\text { Topographical } \\
\text { metrics }\end{array}$ & Abbr. & Metric description \\
\hline Elevation & DEM & Digital elevation model \\
Slope & SLOPE & Gradient of DEM in degree \\
Topographical & TPI & After Wilson et al. (2007) \\
Position Index & & with a surrounding of 17 \\
& & pixels \\
\hline
\end{tabular}

four spectral bands (red, green, blue, near-infrared) were recorded during three flight campaigns in 2010 and 2011 under favorable weather conditions in our study area (Ministerio de Agricultura, Ganadería, Acuacultura y Pesca; Proyecto Sistema Nacional de Informacíon y Gestión de Tierras Rurales e Infraestructura Tecnológica - SIGTIERRAS). We resampled the DEM and orthophotos to $6 \mathrm{~m}$ spatial resolution to match the size of canopy tree crowns. However, mountains and the airborne multi-spectral sensor, which flew at a low height, both casted shadows that appeared in orthophotos. We thus had to mask out those regions where shadows could not be corrected owing to a low contrast of the sensor. These areas were detected using the hillshade tool in the "spatial analyst' of ArcGIS (version 10.3). Furthermore, we corrected the orthophotos topographically in a Java environment following Curatola Fernández et al. (2015). A problem of our procedure is the time lag between taxon sampling and image recording. The change of tree communities is, however, generally slow, and the protected forest habitats investigated (Podocarpus National Park and Reserva Biológica San Francisco) did not substantially change between the sampling of birds in 2000-2002 and the recording of orthophotos in 2010-2011 (Curatola Fernández et al., 2015; Thies et al., 2014). In addition, all investigated plots of the older sampling campaigns plotted on the digital orthophotos were situated in what appeared to be intact forest, and a visual interpretation of the digital orthophotos of the study area did not reveal disturbances (e.g., caused by landslides) or human-induced habitat changes, such as deforestation.

\subsection{Habitat indicators}

We used indicators derived from topography and textural information of RS images for characterizing topographical complexity, vegetation structure and habitat heterogeneity. For the indicators derived from topography, we used three topographical metrics, namely the DEM, the slope calculated in degrees (SLOPE), and a Topographical Position Index (TPI) using the raster package in $\mathrm{R}$ (Hijmans et al., 2015; Table 2). The TPI was calculated according to Wilson et al. (2007) with a surrounding of 17 pixels; this TPI compares the elevation of a pixel with the mean elevation of its environment.

For the indicators derived from textural information, we used the near-infrared (NIR) band and two vegetation indices, namely the normalized difference vegetation index (NDVI), which is based on the red and NIR bands, and an approximation of the anthocyanin reflectance index (ARI), which is based on the red and blue bands 
Table 3

Optical band and vegetation indices used as base layers for the calculation of texture metrics (see Table 3 Appendix A).

\begin{tabular}{|c|c|c|}
\hline Optical metrics & Abbr. & Metric description \\
\hline Near infra-red band & NIR & $\begin{array}{l}\text { Pre-processed near } \\
\text { infra-red band }\end{array}$ \\
\hline $\begin{array}{l}\text { Normalized difference } \\
\text { vegetation index }\end{array}$ & NDVI & $\begin{array}{l}(\mathrm{NIR}-\mathrm{red}) /(\mathrm{NIR}+\mathrm{red}) \\
\text { sensitive to chlorophyll } \\
\text { pigments }\end{array}$ \\
\hline $\begin{array}{l}\text { Anthocyanin } \\
\text { reflectance adjusted } \\
\text { index }\end{array}$ & ARI & $\begin{array}{l}\text { (red - blue)/(red + blue), } \\
\text { sensitive to anthocyanin }\end{array}$ \\
\hline
\end{tabular}

of the multi-spectral orthophotos (Table 3). We chose these indices to account for different vegetation properties that might shape the habitats of our study sites. Both the NIR band and the NDVI are often used as a proxy for biomass or to account for primary productivity (Huete et al., 1997). ARI accounts for the accumulation of anthocyanin pigments in leaves (Gitelson et al., 2001; Sims and Gamon, 2002). Based on the NIR band, NDVI, and ARI, we calculated texture metrics derived from the gray-level co-occurrence matrix using the glcm package in $\mathrm{R}$ (Zvoleff, 2015). Among various texture statistics, we applied the statistics 'mean', 'correlation', and 'entropy' because we identified them as the most uncorrelated ones (Haralick, 1979; Table 3 in Appendix A). We used a moving window size of 17 pixels $\times 17$ pixels matching a surrounding of $102 \mathrm{~m} \times 102 \mathrm{~m}$ to account for textural information within a relatively broad spatial scale. The image textural approach resulted in nine texture metrics. We also calculated texture metrics derived from a second moving window ( 3 pixels $\times 3$ pixels, $18 \mathrm{~m} \times 18 \mathrm{~m}$ ) to account for differences among taxa with regard to the spatial scale of their habitat demands, subsequently used as additional metrics in a second model approach (Table 5 in Appendix A).

All topographical and texture metrics were extracted for the corresponding plots and polygons, respectively, of each taxon. To avoid random noise (pixel values with no relation to the image scene) in predictor images, we extracted the mean of all spatial predictor variables within polygons for ant samples, and we extracted the mean of all spatial predictor variables within a buffer of $10 \mathrm{~m}$ around each sample point for the remaining taxa.

\subsection{Statistical approach}

For the core analysis, we performed partial least-squares (PLS) regressions to model diversity measures for each taxon using textural and topographical metrics. PLS regressions were developed for situations where a low number of samples has to be modeled against a large number of inter-correlated predictor variables (Carrascal et al., 2009). To reduce the number of predictors and to deal with multi-collinearity, PLS regression models derive latent vectors from the predictors that explain the maximum variance of the response variable. Even though this regression is a reliable method, the generation of latent vectors by the PLS algorithm is unfortunately a black-box procedure. Since the structure of latent vectors would change if predictors are added or removed, no precise information on the explained variance of single predictors can be made. Therefore, the possible variety of statistically reasonable predictor combinations could lead to different conclusions about the relationship of species diversity and habitat indicators. We chose those models with the lowest prediction error and subsequently discussed the ecological meaning of these models using the most important predictors.

We used the autopls package in R (Schmidtlein et al., 2012), which implements a variable selection to reduce the size of the set of predictor variables. At the same time, the variable selection reduces computation time, and improves both model performance and interpretability (Andersen and Bro, 2010). This optimization procedure was based on a filter combining significance of predictors estimated by jackknifing and variable importance in the projection (VIP). The VIP scores are based on the weighted sums of the absolute regression coefficients across the number of latent vectors (Chong and Jun, 2005).

Following our proposed aims, we fitted models for species richness and the two NMDS axes characterizing species turnover to compare their performance using the leave-one-out (LOO) validated $\mathrm{R}^{2}$. For all models, we tested the regression residuals for spatial autocorrelation using Moran's I with a neighborhood of five neighbors, but we did not find a significant autocorrelation of the residuals in any of the models $(\mathrm{p}<0.05)$. To identify both the most important predictors for each model and an overall trend among species richness and turnover, we used VIP values as a measure of predictor importance, and regression coefficients as a measure of predictor influence (Chong and Jun, 2005). In general, special emphasis is put on the VIP values greater than one, since the average of squared VIP scores equals one (Mehmood et al., 2012). However, to consider a model-specific VIP cutoff and to facilitate the interpretation of predictor variables, we placed emphasis on all VIP scores greater than the third quartile of all VIP observations in each model.

\section{Results}

\subsection{Species diversity measures}

In general, the composition of species along NMDS axes is often related to species richness. However, we found significant correlations only between species richness and NMDS I for pyraloid moths $(\mathrm{r}=0.82, \mathrm{p}<0.01)$ and a correlation between species richness and NMDS II for ants $(\mathrm{r}=0.66, \mathrm{p}<0.01)$.

Since the three moth taxa were sampled on the same plots, we were able to test for correlations between diversity measures of these taxa. Measures of species richness showed no significant correlations between moth taxa, but correlations were found for NMDS I $(r>|0.95|$ in all three cases; $p<0.01)$ and for NMDS II $(r>|0.81|$; $\mathrm{p}<0.01)$.

\subsection{Predictive power of diversity models}

The predictability of species richness highly varied among taxa, ranging from $4 \%$ of explained variance for arctiinae moths to $78 \%$ for ants (Table 4 ). When image textures from a different window size ( 3 pixels $\times 3$ pixels; $18 \mathrm{~m} \times 18 \mathrm{~m}$ ) were used as additive predictors (Table 5 in Appendix A), the predictive power of species richness of trees and birds increased significantly from $12 \%$ to $22 \%$ and from $13 \%$ to $27 \%$, respectively. In contrast to species richness, the models of NMDS I showed universally high LOO-validated $\mathrm{R}^{2}$ values for all six taxa, ranging from 0.64 (birds) to 0.98 (trees; Table 4). NMDS II showed more variation in model performance among taxa than NMDS I, and ranged from 33\% of explained variance for trees to $74 \%$ for pyraloid moths (Table 4).

\subsection{Predictor importance and influence}

The species richness of both pyraloid moths and ants increased with decreasing DEM values and, in addition, that of ants increased with increasing 'entropy' texture of ARI, while that of pyraloid moths increases with decreasing 'mean' texture of ARI (Fig. 2). By contrast, DEM was not included in the models of geometrid moths and arctiinae moths, and it showed low importance in the models of trees and birds (VIP values < 3 rd quartile, Fig. 2). The species richness of these taxa increased with increasing 'mean' and 'entropy' texture metrics. Tree species richness was negatively associated 
Table 4

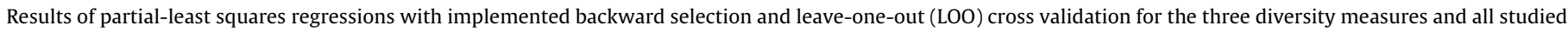
taxa using a set of spatial predictors $(n=12)$.

\begin{tabular}{|c|c|c|c|c|c|}
\hline Species diversity measures & Taxonomic group & $\mathrm{R}^{2}$ & LOO R ${ }^{2}$ & No. of latent vectors & No. of predictors \\
\hline \multirow[t]{6}{*}{ Species richness } & Trees & 0.30 & 0.12 & 2 & 8 \\
\hline & Pyraloidea & 0.84 & 0.72 & 4 & 7 \\
\hline & Geometridae & 0.75 & 0.57 & 4 & 5 \\
\hline & Arctiinae & 0.40 & 0.04 & 2 & 7 \\
\hline & Ants & 0.85 & 0.78 & 2 & 10 \\
\hline & Birds & 0.33 & 0.13 & 1 & 4 \\
\hline \multirow[t]{6}{*}{ NMDS I } & Trees & 0.99 & 0.98 & 7 & 9 \\
\hline & Pyraloidea & 0.96 & 0.94 & 2 & 2 \\
\hline & Geometridae & 0.96 & 0.90 & 3 & 8 \\
\hline & Arctiinae & 0.97 & 0.89 & 6 & 12 \\
\hline & Ants & 0.94 & 0.89 & 4 & 7 \\
\hline & Birds & 0.78 & 0.64 & 3 & 9 \\
\hline \multirow[t]{6}{*}{ NMDS II } & Trees & 0.41 & 0.33 & 2 & 3 \\
\hline & Pyraloidea & 0.95 & 0.74 & 6 & 8 \\
\hline & Geometridae & 0.94 & 0.71 & 9 & 12 \\
\hline & Arctiinae & 0.78 & 0.64 & 2 & 8 \\
\hline & Ants & 0.74 & 0.63 & 2 & 9 \\
\hline & Birds & 0.59 & 0.45 & 2 & 7 \\
\hline
\end{tabular}

with the TPI and positively associated with the 'entropy' statistics of the NIR band (Fig. 2).

Since NMDS I and II are based on ordinations, the direction of predictor influence is arbitrary. NMDS I of all taxa except ants was predicted by DEM; for pyraloid moths, DEM and TPI were the only predictors (Fig. 2). NMDS I of bird species was also predicted by SLOPE and the texture 'correlation' of ARI, whereas NMDS I of trees, geometrid moths, and arctiinae moths was also predicted by additional 'mean' and 'entropy' texture statistics. For trees, NMDS II was predicted by TPI, while DEM and 'mean' and 'entropy' texture statistics together predicted NMDS II of ants (Fig. 2). NMDS II of all ectotherms animals was predicted by 'entropy' texture metrics of NDVI.

\section{Discussion}

Our models revealed considerable variation in the ability of habitat indicators to predict species richness across the six taxa studied. Four out of six taxa were predicted by RS texture metrics, largely independent of elevation. Our models also revealed the high predictability of species turnover assessed by NMDS ordination of all six taxa. A combination of elevation and taxon-specific texture metrics explained species turnover along an elevational gradient, and texture metrics, particularly 'entropy' texture metrics, explained species turnover along more subtle, local changes in habitat structure.

\subsection{Species richness and elevation}

Considering the well-documented response of ectotherms to temperature (e.g., McCain and Grytnes, 2010), it is not surprising that the number of species of pyraloid moths and ants decreased with increasing elevation. Consequently, elevation is a good proxy for the thermal gradient (Fries et al., 2009), but also precipitation and water logging increase (Beck and Kottke, 2008; Fries et al., 2014) and soil fertility and $\mathrm{N}$ availability decrease with increasing elevation (Wolf et al., 2011). In comparison with PLS regression models using 'topography only' as predictor variables (Table 6 in Appendix A), topography would suffice to explain species richness of pyraloid moths, and models for ants slightly benefited from the inclusion of additional texture metrics. In combination with elevation, textural information provided further facets of the environment to model additional variance in species richness, such as 'entropy' statistics of ARI for ants. ARI accounts for the accumula- tion of anthocyanin pigments in leaves (Gitelson et al., 2001; Sims and Gamon, 2002). Anthocyanin pigments are generally higher in senescent leaves but occur also as protection against herbivory mostly in young leaves (Karageorgou and Manetas, 2006), and might protect against UV radiation (Caldwell, 1981; Steyn et al., 2002). Generally, tropical mountain regions have high UV-B levels, which increase with altitude and canopy openness (Flenley, 2011). 'Entropy' statistics account for the degree of disorder (Haralick, 1979) and thus high values of 'entropy' ARI depict a higher vegetation heterogeneity somehow related to anthocyanin pigments in canopy leaves. In addition, 'entropy' ARI decreased with a higher $\mathrm{C} / \mathrm{N}$ ratio in plant tissues $(\mathrm{r}=-0.55, \mathrm{p}<0.01$; Table 4 in Appendix A), which is a proxy for $\mathrm{N}$ availability in forest soils that is related to nutrient use efficiency of plants (Wolf et al., 2011). Therefore, this texture metric might be an important indicator of nutritional quality of foliage for herbivores.

\subsection{Species richness and habitat structure}

Species richness of trees, geometrid and arctiinae moths, and birds showed no significant response to elevation, and models using 'topography only' as predictor variables were weak or even failed to explain the variability of species richness (Table 6 in Appendix A). This indicates that information from topography cannot predict the diversity of these taxa successively, which confirms the findings regarding species richness of geometrid moths in Brehm et al. (2016).

Species richness of trees, geometrid moths, arctiinae moths and birds was better predicted by textural predictors, such as 'mean' NIR for geometrid moths and birds, and 'entropy' NDVI/ARI for arctiinae moths. For our study area, Pearson correlations suggested that 'mean' and 'entropy' texture metrics were equal or even more highly related to site-based forest productivity data $(\mathrm{r}=0.40-0.78$, $\mathrm{p}<0.01)$ than topographical metrics $(\mathrm{r}=0.38-0.64, \mathrm{p}<0.01$; Table 4 in Appendix A). We suppose that 'entropy' statistics of the NIR band and NDVI thus depict a high diversity of vegetation types. This habitat heterogeneity, which is probably related to a high structural complexity in ravine forests or forest edges, might support more coexisting species.

Particularly the predictability of geometrid moths that explains $57 \%$ of species richness should be noted because earlier studies that assessed only the effects of temperature or elevation revealed much less predictive power $(\max (|\mathrm{r}|)=0.29 ; \mathrm{p}>0.24$, Brehm et al., 2016; $\mathrm{R}^{2}=0.0243, \mathrm{p}>0.488$, Fiedler et al., 2008). As suggested in Stein et al. 


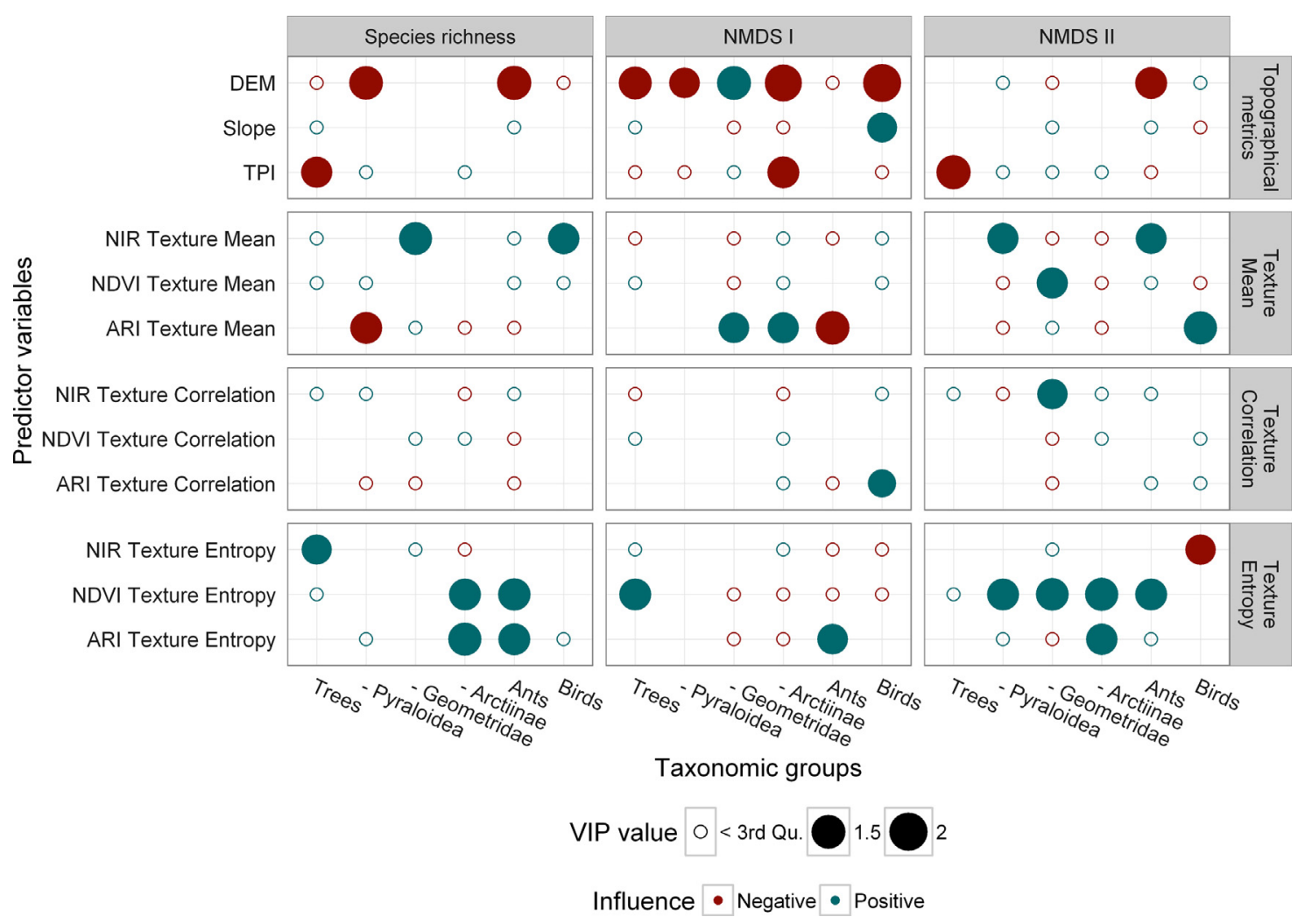

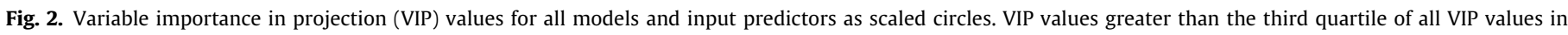

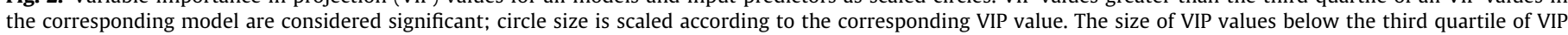
observations is fixed and indicated by open circles. Direction of predictor influence was extracted from regression coefficients and is indicated by color.

(2014), habitat heterogeneity might be more important for certain herbivores than climatic or topographical heterogeneity since different clades of moth species have developed distinct biological features to cope with environmental factors such as temperature (Braga and Diniz, 2015). By contrast, arctiinae moths comprise a speciose clade of which a large amount of caterpillar species are not classical herbivores as they feed on dead or withered leaves or epiphylls (Bodner et al., 2015; Seifert et al., 2016). Therefore, it is not surprising that neither topographical nor texture metrics as proxies for habitat heterogeneity (dominated by tree crowns) were able to model the species richness of arctiinae moths successively.

Although the predictability of species richness of trees and birds was low, we showed that it significantly increased when texture metrics of multiple window sizes were used (Table 5 in Appendix A), as recommended by Mairota et al. (2015) to match the approximate scale of activity (e.g., home ranges) among species of the targeted taxonomic group. Birds were sampled only along a short stretch of the elevational gradient (700 m; Fig. 1), which might cause a higher dependence of species richness on habitat heterogeneity than on topography. However, general patterns of bird species richness remain unclear because of contrasting results obtained in tropical forests along elevational gradients, ranging from increasing bird species richness with higher habitat heterogeneity (Wallis et al., 2016b), to decreasing species richness with increasing elevation (Jankowski et al., 2013), to a hump-shaped relationship between elevation and species richness (Herzog et al., 2005).

Our models of tree species richness were associated with negative TPI values that represent locations that are on average lower in elevation than its surrounding and that have lower values of 'correlation' NDVI, which indicated areas of uniform NDVI values. Thus, in accordance with Werner and Homeier (2015), higher tree species richness might occur in valleys where the canopy is higher and denser (= high leaf area index) representing higher soil nutrient availability compared to upper slopes and ridges. The low to moderate predictive power of tree species richness found in this study and in earlier studies that assessed multi-spectral RS metrics (e.g., Fricker et al., 2015) lead to the need for information on more subtle variance in either habitat characteristics or the spectral response of woody plant species in the canopy. Variables derived from RS information with higher spectral resolution, as recommended by Asner and Martin (2011), have been successfully used to model tropical tree alpha-diversity (Féret and Asner, 2014; Schäfer et al., 2016). For example, Vaglio Laurin et al. (2014) have shown that hyperspectral data explain up to $84.9 \%$ of the alpha-diversity of upper canopy trees in a West African forest, whereas common vegetation indices yield poor results. We therefore propose that pigment-related hyperspectral data would be more successful in modeling tree species richness than habitat heterogeneity assessed with image texture metrics.

\subsection{Species turnover along environmental gradients}

Models for species turnover showed far higher predictive power among all taxa than models for species richness. The scores along the first NMDS axis were strongly associated with elevation. By contrast, the scores of the second NMDS axis showed a response to the elevational gradient only for ants. Species have evolved specific adaptations to climatic zones that influence their distribution (Angilletta Jr., 2009; for ants, e.g., Bishop et al., 2015; for geometrid moths, e.g., Brehm et al., 2003; for other moths species, e.g., Fiedler et al., 2008). Thus, it is not surprising that the elevational gradient is crucially important for the compositional change (Guerin et al., 2013). It is obvious that other factors besides elevation influenced 
the composition and turnover of the investigated assemblages, but our results underline the importance of elevation for shaping an important part of species turnover of almost all taxa, from primary producers to herbivores, detritivores, and predators.

The scores of the second dimension of NMDS ordination (for ants, the first NMDS axis) indicated a change in species composition predicted by texture metrics that characterize local habitat heterogeneity. Assemblages of all taxonomic groups of moths and ants changed with primary productivity and habitat heterogeneity ('entropy' NDVI), or in the case of arctiinae moths, with variation in ARI, which is related to the $\mathrm{C} / \mathrm{N}$ ratio in understory plant tissues. This might explain the small-scaled compositional change in species assemblages along forest edges or glades to forests with a higher canopy cover, as observed in the study area for a range of organisms (Brehm et al., 2003; Hilt et al., 2006; Hilt and Fiedler, 2006; Wallis et al., 2016b). Thus, the second ordination axis appears to account for compositional variation of communities along a habitat structural gradient, largely independent of elevation.

\section{Conclusions}

Indicator applications differed among both the taxa and diversity measures studied owing to distinct variation in patterns of species distribution. Species richness models of trees, geometrid moths, and birds highly benefited from integrating RS-based texture metrics. By contrast, topographical metrics sufficiently modeled species richness of pyraloid moths and ants. Models of species turnover can be constructed across taxonomic groups with far higher predictability than models of species richness. The two ordination axes effectively separated compositional change along the elevational gradient (NMDS I) from more subtle, changes in habitat structure, which were surrogated by RS-based texture metrics (NMDS II). However, we have to stress that the interpretation of causal relationships between RS texture metrics and species diversity is sometimes difficult and that field based inventories are still necessary to calibrate RS proxies. In addition, airborne RS missions are often not repeated and thus lack a temporal aspect, which is essential for recurrent monitoring. We therefore recommend to obtain habitat indicators from upcoming missions of satellites with a fine to moderate spatial and temporal resolution (e.g., Sentinel-2 mission; Drusch et al., 2012), which would allow the generation of cloud-free composites for different time spans. Hence, textural information derived from future satellite missions as habitat indicators would allow monitoring species diversity of a range of taxa successively in space and time.

\section{Acknowledgements}

This study was conducted in the framework of the German Research Foundation (DFG) projects FI 547/5-1 to 5-3 and the Research Units FOR 402, FOR 816 (subproject A1 HO3296/2-2), and PAK 823-825 (subproject C2 BE1780/34-1, BR1293/11, FA925/71, ZI698/8-1). We are grateful to the DFG (PAK 825/1) for funding our project, to the Ecuadorian Ministry of the Environment (MAE) for permission to conduct research, and to the foundation Nature and Culture International (NCI) for logistic support. We acknowledge the support of all our research assistants who helped with field work and sample processing. The Ministerio de Agricultura, Ganadería, Acuacultura y Pesca kindly provided the SIGTIERRAS orthophotos, which were the basis of our approach. We thank Karen A. Brune for linguistic revision of the manuscript. Special thanks go to two anonymous reviewers for constructive comments.

\section{Appendix A.}

Table A1

Number of rarefied and extrapolated samples of tree and moth species covering $70 \%$ of the asymptotic richness. Sum of each row reveal the total number of samples.

\begin{tabular}{lrrr}
\hline Taxonomic group & $\begin{array}{r}\text { No. of samples } \\
\text { using rarefied } \\
\text { species richness }\end{array}$ & $\begin{array}{r}\text { No. of samples } \\
\text { using extrapolated } \\
\text { species richness }\end{array}$ & $\begin{array}{r}\text { No. of samples } \\
\text { using observed } \\
\text { species richness }\end{array}$ \\
\hline Trees & 28 & 21 & 1 \\
Pyraloidea & 20 & 0 & 0 \\
Geometridae & 20 & 0 & 0 \\
Arctiinae & 18 & 2 & 0
\end{tabular}

Table A2

Stress values for the first two dimensions of NMDS ordinations.

\begin{tabular}{lrr}
\hline Taxonomic group & 1 Dimension & 2 Dimensions \\
\hline Trees & 0.136 & 0.080 \\
Pyraloidea & 0.101 & 0.071 \\
Geometridae & 0.098 & 0.057 \\
Arctiinae & 0.140 & 0.080 \\
Ants & 0.207 & 0.118 \\
Birds & 0.330 & 0.171 \\
\hline
\end{tabular}

Table A3

Texture statistics derived from gray-level co-occurrence matrices calculated from optical metrics (see Table 1). For the moving window approach that shifts in all directions, one window size was considered within the core analysis ( 3 pixels $\times 3$ pixels). Image texture metrics derived from an additional window size (17 pixels $\times 17$ pixels) to cope with different habitat scales of all taxonomic groups was used for a second model (Table 5 in Appendix A).

\begin{tabular}{ll}
\hline Texture statistics & Equation \\
\hline Mean & $M E=\sum_{i, j=0}^{N-1}\left(p_{i, j}\right)$ \\
Entropy & $E N=\sum_{i, j=0}^{N-1} p_{i, j}\left(-\ln p_{i, j}\right)$ \\
Correlation & $C C=\sum_{i, j=0}^{N-1} p_{i, j}\left[\frac{(i-M E)(j-M E)}{\sqrt{V A_{i} V A_{j}}}\right]$ \\
\hline With $p_{i, j}=V_{i, j} \sum_{i, j=0}^{N-1} V_{i, j}$, where $V_{\mu}$ is the value in cell $i, j$ and $\mathrm{N}$ is the number of rows
\end{tabular}

Table A4

Pearson correlation coefficients of habitat indicators and tree growth parameters. For all derived habitat indicators, we performed a correlation analysis with tree growth parameters derived from a plot-based inventory (Homeier et al., unpublished). Pearson's correlation coefficients depended on different numbers of samples. Data on stem diameter at breast height, above ground biomass increment (AGBi), and a measure of aboveground net primary production (NPPa; combination of AGBi and leaf litter production) were collected, and tree species were sampled $(n=50)$. In addition, we measured the $\mathrm{C} / \mathrm{N}$ ratio of leaves in understory plants and sampled ant species $(n=27)$. Significant correlation coefficients are highlighted in bold. DEM, Digital elevation model; SLOPE, slope in degrees; TPI, topographical position index; NIR, near-infrared band; NDVI, normalized difference vegetation index; ARI, anthocyanin reflectance index.

\begin{tabular}{|c|c|c|c|c|c|}
\hline \multirow[b]{2}{*}{ Habiat indicators } & \multicolumn{5}{|c|}{ Pearson correlation coefficient } \\
\hline & Stem size & & AGBi & $\mathrm{NPPa}$ & $\mathrm{C} / \mathrm{N}$ ratio \\
\hline DEM & & $0.38^{*}$ & $-0.64 *$ & $-0.64^{*}$ & 0.41 \\
\hline SLOPE & & 0.28 & 0.13 & 0.29 & -0.46 \\
\hline TPI & & -0.20 & 0.28 & 0.13 & 0.41 \\
\hline NIR mean & & -0.32 & $0.59^{*}$ & $0.78^{*}$ & -0.08 \\
\hline NDVI mean & & $-0.40^{*}$ & $0.62^{*}$ & $0.75^{*}$ & -0.19 \\
\hline ARI mean & & 0.11 & 0.09 & 0.33 & 0.24 \\
\hline NIR correlation & & -0.22 & 0.19 & 0.27 & -0.31 \\
\hline NDVI correlation & & 0.07 & 0.04 & -0.11 & -0.44 \\
\hline ARI correlation & & -0.03 & -0.01 & 0.03 & -0.39 \\
\hline NIR entropy & & -0.36 & $0.58^{*}$ & $0.74^{*}$ & 0.19 \\
\hline NDVI entropy & & $-0.49 *$ & $0.64^{*}$ & $0.56^{*}$ & -0.42 \\
\hline ARI entropy & & -0.32 & 0.35 & 0.13 & $-0.55^{*}$ \\
\hline$* p<0.01$ & & & & & \\
\hline
\end{tabular}


Table A5

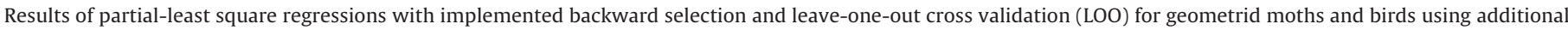

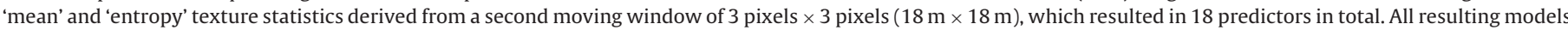
included texture statistics from the additional smaller window after backward selection. LOO $\mathrm{R}^{2}$ values higher than those in Table 4 are in bold.

\begin{tabular}{|c|c|c|c|c|c|}
\hline Species diversity measures & Taxonomic group & $\mathrm{R}^{2}$ & LOO R ${ }^{2}$ & No. of latent vectors & No. of predictors \\
\hline Species & Trees & 0.49 & 0.22 & 5 & 9 \\
\hline \multirow[t]{5}{*}{ richness } & Pyraloidea & 0.77 & 0.48 & 2 & 11 \\
\hline & Geometridae & 0.75 & 0.57 & 2 & 8 \\
\hline & Arctiinae & 0.38 & 0.09 & 2 & 12 \\
\hline & Ants & 0.80 & 0.74 & 2 & 10 \\
\hline & Birds & 0.61 & 0.27 & 5 & 9 \\
\hline \multirow[t]{6}{*}{ NMDS I } & Trees & 0.99 & 0.98 & 7 & 10 \\
\hline & Pyraloidea & 0.94 & 0.87 & 2 & 12 \\
\hline & Geometridae & 0.96 & 0.93 & 2 & 13 \\
\hline & Arctiinae & 0.96 & 0.93 & 2 & 10 \\
\hline & Ants & 0.94 & 0.90 & 4 & 10 \\
\hline & Birds & 0.80 & 0.68 & 3 & 11 \\
\hline \multirow[t]{6}{*}{ NMDS II } & Trees & 0.42 & 0.29 & 3 & 6 \\
\hline & Pyraloidea & 0.89 & 0.82 & 2 & 9 \\
\hline & Geometridae & 0.79 & 0.62 & 2 & 7 \\
\hline & Arctiinae & 0.83 & 0.72 & 2 & 11 \\
\hline & Ants & 0.82 & 0.75 & 3 & 7 \\
\hline & Birds & 0.66 & 0.53 & 2 & 8 \\
\hline
\end{tabular}

\section{Table A6}

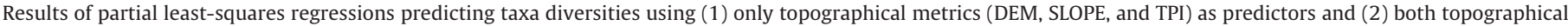

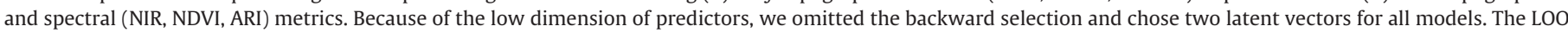

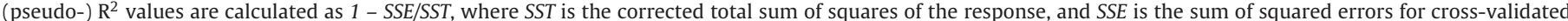

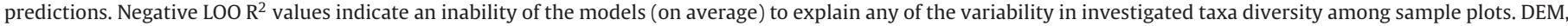

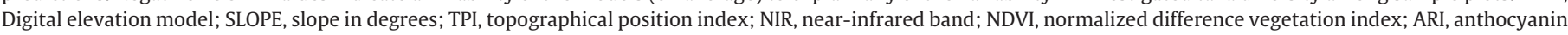
reflectance index.

\begin{tabular}{|c|c|c|c|c|c|}
\hline \multirow[b]{2}{*}{ Species diversity measures } & \multirow[b]{2}{*}{ Taxonomic group } & \multicolumn{2}{|c|}{ Topographical metrics only } & \multicolumn{2}{|c|}{ Topographical and spectral metric } \\
\hline & & $\mathrm{R}^{2}$ & LOO R $\mathrm{R}^{2}$ & $\mathrm{R}^{2}$ & $\mathrm{LOO} \mathrm{R}^{2}$ \\
\hline \multirow{6}{*}{$\begin{array}{l}\text { Species } \\
\text { richness }\end{array}$} & Trees & 0.20 & 0.08 & 0.22 & 0.10 \\
\hline & Pyraloidea & 0.82 & 0.77 & 0.79 & 0.71 \\
\hline & Geometridae & 0.02 & -0.68 & 0.64 & 0.51 \\
\hline & Arctiinae & 0.11 & -0.27 & 0.11 & -0.41 \\
\hline & Ants & 0.80 & 0.75 & 0.81 & 0.77 \\
\hline & Birds & 0.15 & -0.01 & 0.16 & -0.11 \\
\hline \multirow[t]{6}{*}{ NMDS I } & Trees & 0.98 & 0.98 & 0.98 & 0.98 \\
\hline & Pyraloidea & 0.96 & 0.94 & 0.95 & 0.93 \\
\hline & Geometridae & 0.96 & 0.94 & 0.96 & 0.93 \\
\hline & Arctiinae & 0.93 & 0.86 & 0.95 & 0.92 \\
\hline & Ants & 0.21 & -0.03 & 0.87 & 0.82 \\
\hline & Birds & 0.74 & 0.7 & 0.74 & 0.65 \\
\hline \multirow[t]{6}{*}{ NMDS II } & Trees & 0.34 & 0.26 & 0.07 & -0.05 \\
\hline & Pyraloidea & 0.04 & -0.87 & 0.52 & 0.30 \\
\hline & Geometridae & 0.01 & -0.86 & 0.30 & -0.01 \\
\hline & Arctiinae & 0.06 & -0.86 & 0.41 & 0.07 \\
\hline & Ants & 0.61 & 0.51 & 0.65 & 0.58 \\
\hline & Birds & 0.01 & -0.2 & 0.01 & -0.15 \\
\hline
\end{tabular}

\section{References}

Andersen, C.M., Bro, R., 2010. Variable selection in regression-a tutorial. J. Chemom. 24, 728-737, http://dx.doi.org/10.1002/cem.1360.

Angilletta Jr., M.J., 2009. Thermal Adaptation. University Press, Oxford.

Asner, G.P., Martin, R.E., 2011. Canopy phylogenetic, chemical and spectral assembly in a lowland Amazonian forest. New Phytol. 189, 999-1012, http:// dx.doi.org/10.1111/j.1469-8137.2010.03549.x.

Banks-Leite, C., Cintra, R., 2008. The heterogeneity of Amazonian treefall gaps and bird community composition. Ecotropica 14, 1-13.
Beck, E.H., Kottke, I.L., 2008. Facing a hotspot of tropical biodiversity. Basic Appl. Ecol. 9, 1-3, http://dx.doi.org/10.1016/j.baae.2007.06.017.

Beck, E., Makeschin, F., Haubrich, F., Richter, M., Bendix, J., Valerezo, C., 2008. The Ecosystem (Reserva Biológica San Francisco). In: Beck, E., Bendix, J., Kottke, I. Makeschin, F., Mosandl, R. (Eds.), Gradients in a Tropical Mountain Ecosystem of Ecuador. Springer, Berlin, Heidelberg, pp. 1-13.

Beck, J., Brehm, G., Fiedler, K., 2011. Links between the environment, abundance and diversity of Andean moths. Biotropica 43, 208-217, http://dx.doi.org/10. 1111/j.1744-7429.2010.00689.x.

Bendix, J., Beck, E., 2016. Environmental change and its impacts in a biodiversity hotspot of the south Ecuadorian Andes - monitoring and mitigation strategies. Erdkunde 70, 1-4, http://dx.doi.org/10.3112/erdkunde.2016.01.01. 
Bendix, J., Rollenbeck, R., Göttlicher, D., Cermak, J., 2006. Cloud occurrence and cloud properties in Ecuador. Clim. Res. 30, 133-147, http://dx.doi.org/10.3354 cr030133.

Bendix, J., Rollenbeck, R., Richter, M., Fabian, P., Emck, P., 2008. Climate. In: Beck, E. Bendix, J., Kottke, I., Makeschin, F., Mosandl, R. (Eds.), Gradients in a Tropical Mountain Ecosystem of Ecuador. Springer, Berlin, Heidelberg, pp. 63-73.

Bishop, T.R., Robertson, M.P., van Rensburg, B.J., Parr, C.L., 2015. Contrasting species and functional beta diversity in montane ant assemblages. J. Biogeogr. 42 1776-1786, http://dx.doi.org/10.1111/jbi.12537.

Bodner, F., Brehm, G., Fiedler, K., 2015. Many caterpillars in a montane rain forest in Ecuador are not classical herbivores. J. Trop. Ecol. 31, 473-476, http://dx.dol. org/10.1017/S0266467415000243.

Braga, L., Diniz, I.R., 2015. Importance of habitat heterogeneity in richness and diversity of moths (Lepidoptera) in Brazilian savanna. Environ. Entomol. 44 499-508, http://dx.doi.org/10.1093/ee/nvv026.

Brehm, G., Fiedler, K., 2004. Ordinating tropical moth ensembles from an elevational gradient: a comparison of common methods. J. Trop. Ecol. 20, 165-172, http://dx.doi.org/10.1017/S0266467403001184.

Brehm, G., Fiedler, K., 2010. Geometridae species abundance 1999-2000 (species-site matrix). https://doi.org/10.5678/LCRS/PAK823-825.DAT.1548.

Brehm, G., Homeier, J., Fiedler, K., 2003. Beta diversity of geometrid moths (Lepidoptera: Geometridae) in an Andean montane rainforest. Divers. Distrib. 9, 351-366, http://dx.doi.org/10.1046/j.1472-4642.2003.00023.x.

Brehm, G., Homeier, J., Fiedler, K., Kottke, I., Illig, J., Nöske, N.M., Werner, F.A., Breckle, S.W., 2008. Mountain rain forests in Southern Ecuador as a hotspot of biodiversity - limited knowledge and diverging Patterns. In: Beck, E., Bendix, J. Kottke, I., Makeschin, F., Mosandl, R. (Eds.), Gradients in a Tropical Mountain Ecosystem of Ecuador. Springer, Berlin, Heidelberg, pp. 15-23.

Brehm, G., Hebert, P.D.N., Colwell, R.K., Adams, M.-O., Bodner, F., Friedemann, K, Möckel, L., Fiedler, K., 2016. Turning up the heat on a hotspot: DNA barcodes reveal $80 \%$ more species of geometrid moths along an Andean elevational gradient. PLoS One 11, e0150327, http://dx.doi.org/10.1371/journal.pone. 0150327.

Brehm, G., 2002. Diversity of geometrid moths in a montane rainforest in Ecuador (Doctoral thesis). Bayreuth.

Caldwell, M.M., 1981. Plant response to solar ultraviolet radiation. In: Lange, O.L., Nobel, P.S., Osmond, C.B., Ziegler, H. (Eds.), Physiological Plant Ecology I. Springer, Berlin, Heidelberg, pp. 169-197.

Carrascal, L.M., Galván, I., Gordo, O., 2009. Partial least squares regression as an alternative to current regression methods used in ecology. Oikos 118 681-690, http://dx.doi.org/10.1111/j.1600-0706.2008.16881.x.

Chong, I.-G., Jun, C.-H., 2005. Performance of some variable selection methods when multicollinearity is present. Chemom. Intell. Lab. Syst. 78, 103-112.

Cintra, R., Naka, L.N., 2012. Spatial variation in bird community composition in relation to topographic gradient and forest heterogeneity in a central Amazonian rainforest. Int. J. Ecol. 2012, 1-25, http://dx.doi.org/10.1155/2012/ 435671.

Colwell, R.K., Chao, A., Gotelli, N.J., Lin, S.-Y., Mao, C.X., Chazdon, R.L., Longino, J.T., 2012. Models and estimators linking individual-based and sample-based rarefaction, extrapolation and comparison of assemblages. J. Plant Ecol. 5 , 3-21, http://dx.doi.org/10.1093/jpe/rtr044.

Couteron, P., Pelissier, R., Nicolini, E.A., Paget, D., 2005. Predicting tropical forest stand structure parameters from Fourier transform of very high-resolution remotely sensed canopy images. J. Appl. Ecol. 42, 1121-1128, http://dx.doi.org/ 10.1111/j.1365-2664.2005.01097.x.

Culbert, P.D., Radeloff, V.C., St-Louis, V., Flather, C.H., Rittenhouse, C.D., Albright T.P., Pidgeon, A.M., 2012. Modeling broad-scale patterns of avian species richness across the Midwestern United States with measures of satellite image texture. Remote Sens. Environ. 118, 140-150, http://dx.doi.org/10.1016/j.rse. 2011.11 .004

Curatola Fernández, G., Obermeier, W., Gerique, A., Sandoval, M., Lehnert, L., Thies, B., Bendix, J., 2015. Land cover change in the Andes of Southern Ecuador-patterns and drivers. Remote Sens. 7, 2509-2542, http://dx.doi.org/ $10.3390 /$ rs 70302509.

Domínguez, D.F., Bustamante, M., Albuja, R., Castro, A., Lattke, J.E., Donoso, D.A., 2016. COI barcodes for ants (Hymenoptera: Formicidae) of drylands in the south of Ecuador. Ecosistemas 25, 76-78, http://dx.doi.org/10.7818/ECOS. 2016.25-2.09.

Donoso, D.A., Ramón, G., 2009. Composition of a high diversity leaf litter ant community (Hymenoptera: Formicidae) from an Ecuadorian pre-montane rainforest. Ann. Soc. Entomol. Fr. NS 45, 487-499, http://dx doi.org/10.1080/ 00379271.2009.10697631.

Drusch, M., Del Bello, U., Carlier, S., Colin, O., Fernandez, V., Gascon, F., Hoersch, B. Isola, C., Laberinti, P., Martimort, P., Meygret, A., Spoto, F., Sy, O., Marchese, F. Bargellini, P., 2012. Sentinel-2: ESA's optical high-resolution mission for GMES operational services. Remote Sens. Environ. 120, 25-36, http://dx.doi.org/10. 1016/j.rse.2011.11.026.

Estes, L.D., Reillo, P.R., Mwangi, A.G., Okin, G.S., Shugart, H.H., 2010. Remote sensing of structural complexity indices for habitat and species distribution modeling. Remote Sens. Environ. 114, 792-804, http://dx.doi.org/10.1016/j.rse. 2009.11.016.

Féret, J.-B., Asner, G.P., 2014. Mapping tropical forest canopy diversity using high-fidelity imaging spectroscopy. Ecol. Appl. 24, 1289-1296, http://dx.doi. org/10.1890/13-1824.1.
Farwig, N., Lung, T., Schaab, G., Böhning-Gaese, K., 2014. Linking land-use scenarios, remote sensing and monitoring to project impact of management decisions. Biotropica 46, 357-366, http://dx.doi.org/10.1111/btp.12105.

Feilhauer, H., Schmidtlein, S., 2009. Mapping continuous fields of forest alpha and beta diversity. Appl. Veg. Sci. 12, 429-439, http://dx.doi.org/10.1111/j.1654109X.2009.01037.x.

Fiedler, K., Brehm, G., Hilt, N., Süßenbach, D., Häuser, C.L., 2008. Variation of diversity patterns across moth families along a tropical elevational gradient. In: Beck, E., Bendix, J., Kottke, I., Makeschin, F., Mosandl, R. (Eds.), Gradients in a Tropical Mountain Ecosystem of Ecuador. Springer, Berlin, Heidelberg, pp. 167-179.

Flenley, J.R., 2011. Ultraviolet insolation and the tropical rainforest: altitudinal variations, Quaternary and recent change, extinctions, and the evolution of biodiversity. In: Bush, M., Flenley, J., Gosling, W. (Eds.), Tropical Rainforest Responses to Climatic Change. Springer, Berlin, Heidelberg, pp. 241-258.

Fricker, G.A., Wolf, J.A., Saatchi, S.S., Gillespie, T.W., 2015. Predicting spatial variations of tree species richness in tropical forests from high-resolution remote sensing. Ecol. Appl. 25, 1776-1789, http://dx.doi.org/10.1890/14-1593.

Fries, A., Rollenbeck, R., Göttlicher, D., Nauß, T., Homeier, J., Peters, T., Bendix, J., 2009. Thermal structure of a megadiverse Andean mountain ecosystem in southern Ecuador and its regionalization. Erdkunde 63, 321-335, http://dx.doi. org/10.3112/erdkunde.2009.04.03.

Fries, A., Rollenbeck, R., Bayer, F., Gonzalez, V., Oñate-Valivieso, F., Peters, T., Bendix, J., 2014. Catchment precipitation processes in the San Francisco valley in southern Ecuador: combined approach using high-resolution radar images and in situ observations. Meteorol. Atmos. Phys. 126, 13-29, http://dx.doi.org/ 10.1007/s00703-014-0335-3.

Gerlach, J., Samways, M., Pryke, J., 2013. Terrestrial invertebrates as bioindicators: an overview of available taxonomic groups. J. Insect Conserv. 17, 831-850, http://dx.doi.org/10.1007/s10841-013-9565-9.

Gitelson, A., Merzlyak, M., Zur, Y., Stark, R., Gritz, U., 2001. Non-destructive and remote sensing techniques for estimation of vegetation status. Pap. Nat. Resour. 273, 205-210.

Goetz, S., Steinberg, D., Dubayah, R., Blair, R., 2007. Laser remote sensing of canopy habitat heterogeneity as a predictor of bird species richness in an eastern temperate forest. Remote Sens. Environ. 108 (3), 254-263 http://dx.doi.org/10. 1016/j.rse.2006.11.016.

Gu, H., Singh, A., Townsend, P.A., 2015. Detection of gradients of forest composition in an urban area using imaging spectroscopy. Remote Sens. Environ. 167 168-180, http://dx.doi.org/10.1016/j.rse.2015.06.010.

Guerin, G.R., Biffin, E., Lowe, A.J., 2013. Spatial modelling of species turnover identifies climate ecotones, climate change tipping points and vulnerable taxonomic groups. Ecography 36, 1086-1096, http://dx.doi.org/10.1111/j. 1600-0587.2013.00215.x.

Haralick, R.M., 1979. Statistical and structural approaches to texture. Proc. IEEE, 786-804, http://dx.doi.org/10.1109/proc.1979.11328.

Herzog, S.K., Kessler, M., Bach, K., 2005. The elevational gradient in Andean bird species richness at the local scale: a foothill peak and a high-elevation plateau. Ecography 28, 209-222, http://dx.doi.org/10.1111/j.0906-7590.2005.03935.x.

Hijmans, R.J., Etten, J., van, Cheng, J., Mattiuzzi, M., Sumner, M., Greenberg, J.A., Lamigueiro, O.P., Bevan, A., Racine, E.B., Shortridge, A., 2015. raster: geographic data analysis and modeling.

Hilt, N., Fiedler, K., 2006. Arctiid moth ensembles along a successional gradient in the Ecuadorian montane rain forest zone: how different are subfamilies and tribes? J. Biogeogr. 33, 108-120, http://dx.doi.org/10.1111/j.1365-2699.2005. 01360.x

Hilt, N., Brehm, G., Fiedler, K., 2006. Diversity and ensemble composition of geometrid moths along a successional gradient in the Ecuadorian Andes. J. Trop. Ecol. 22, http://dx.doi.org/10.1017/s0266467405003056.

Homeier, J., Werner, F.A., Gradstein, S.R., Breckle, S., Richter, M., 2008. Potential vegetation and floristic composition of Andean forests in South Ecuador, with a focus on the RBSF. Ecol. Stud. 198, 87-100.

Homeier, J., Breckle, S.-W., Günter, S., Rollenbeck, R.T., Leuschner, C., 2010. Tree diversity, forest structure and productivity along altitudinal and topographical gradients in a species-rich Ecuadorian montane rain forest: Ecuadorian montane forest diversity and structure. Biotropica 42, 140-148, http://dx.doi. org/10.1111/j.1744-7429.2009.00547.x.

Hsieh, T.C., Ma, K.H., Chao, A., 2016. iNEXT: interpolation and extrapolation for species diversity.

Huete, A.R., Liu, H., van Leeuwen, W.J.D., 1997. The use of vegetation indices in forested regions: issues of linearity and saturation, in: Geoscience and Remote Sensing, 1997. IGARSS '97. Remote Sensing - A Scientific Vision for Sustainable Development., 1997 IEEE International. Presented at the Geoscience and Remote Sensing, 1997. IGARSS '97. Remote Sensing - A Scientific Vision for Sustainable Development., 1997 IEEE International, pp. 1966-1968, vol.4, doi: 10.1109/IGARSS.1997.609169.

Jankowski, J.E., Merkord, C.L., Rios, W.F., Cabrera, K.G., Revilla, N.S., Silman, M.R., 2013. The relationship of tropical bird communities to tree species composition and vegetation structure along an Andean elevational gradient. J. Biogeogr. 40, 950-962, http://dx.doi.org/10.1111/jbi.12041.

Kübler, D., Hildebrandt, P., Günter, S., Stimm, B., Weber, M., Mosandl, R., Muñoz, J., Cabrera, O., Zeilinger, J., Silva, B., 2016. Assessing the importance of topographic variables for the spatial distribution of tree species in a tropical mountain forest. Erdkunde 70, 19-47, http://dx.doi.org/10.3112/erdkunde.2016.01.03. 
Karageorgou, P., Manetas, Y., 2006. The importance of being red when young: anthocyanins and the protection of young leaves of Quercus coccifera from insect herbivory and excess light. Tree Physiol. 26, 613-621, http://dx.doi.org/ 10.1093/treephys/26.5.613.

Kati, V., Devillers, P., Dufrêne, M., Legakis, A., Vokou, D., Lebrun, P., 2004. Testing the value of six taxonomic groups as biodiversity indicators at a local scale. Conserv. Biol. 18, 667-675.

Kelsey, K., Neff, J., 2014. Estimates of aboveground biomass from texture analysis of Landsat imagery. Remote Sens. 6, 6407-6422, http://dx.doi.org/10.3390/ rs6076407.

Lu, D., Batistella, M., 2005. Exploring TM image texture and its relationships with biomass estimation in Rondônia, Brazilian Amazon. Acta Amaz. 35, 249-257, http://dx.doi.org/10.1590/S0044-59672005000200015.

Müller, J., Moning, C., Bässler, C., Heurich, M., Brandl, R., 2009. Using airborne laser scanning to model potential abundance and assemblages of forest passerines. Basic Appl. Ecol. 10, 671-681, http://dx.doi.org/10.1016/j.baae.2009.03.004.

Mairota, P., Cafarelli, B., Labadessa, R., Lovergine, F., Tarantino, C., Lucas, R.M. Nagendra, H., Didham, R.K., 2015. Very high resolution Earth observation features for monitoring plant and animal community structure across multiple spatial scales in protected areas. Int. J. Appl. Earth Obs. Geoinf. 37, 100-105 http://dx.doi.org/10.1016/j.jag.2014.09.015.

Malsch, A.K.F., Fiala, B., Maschwitz, U., Maryati Mohamed, D., Jamili, N., Linsenmair, K.E., 2008. An analysis of declining ant species richness with increasing elevation at Mount Kinabalu, Sabah, Borneo. Asian Myrmecol. 2, 33-49.

McCain, C.M., Grytnes, J.-A., 2010. Elevational gradients in species richness. In: John Wiley \& Sons, Ltd (Ed.), Encyclopedia of Life Sciences. John Wiley \& Sons, Ltd, Chichester, UK.

Mehmood, T., Liland, K.H., Snipen, L., Sæbø, S., 2012. A review of variable selection methods in Partial Least Squares Regression. Chemom. Intell. Lab. Syst. 118, 62-69, http://dx.doi.org/10.1016/j.chemolab.2012.07.010.

Muenchow, J., Feilhauer, H., Bräuning, A., Rodríguez, E.F., Bayer, F., Rodríguez, R.A., von Wehrden, H., 2013. Coupling ordination techniques and GAM to spatially predict vegetation assemblages along a climatic gradient in an ENSO-affected region of extremely high climate variability. J. Veg. Sci. 24, 1154-1166, http:/| dx.doi.org/10.1111/jvs.12038.

Nakamura, A., Burwell, C.J., Ashton, L.A., Laidlaw, M.J., Katabuchi, M., Kitching, R.L., 2015. Identifying indicator species of elevation: comparing the utility of woody plants, ants and moths for long-term monitoring: identifying indicator species of elevation. Austral. Ecol. 41, 179-188, http://dx.doi.org/10.1111/aec.12291.

Paulsch, D., Müller-Hohenstein, K., 2008. Fauna: composition and function. In: Beck, E., Bendix, J., Kottke, I., Makeschin, F., Mosandl, R. (Eds.), Gradients in a Tropical Mountain Ecosystem of Ecuador. Springer, Berlin, Heidelberg, pp. 149-156.

Paulsch, D., Wallis, C., 2016. Bird species abundance 2000-2002 (species-site matrix). https://doi.org/10.5678/lcrs/pak823-825.dat.1462.

Peters, M.K., Mayr, A., Röder, J., Sanders, N.J., Steffan-Dewenter, I., 2014. Variation in nutrient use in ant assemblages along an extensive elevational gradient on $\mathrm{Mt}$ Kilimanjaro. J. Biogeogr. 41, 2245-2255, http://dx.doi.org/10.1111/jbi.12384.

R Core Team, 2016. R: A Language and Environment for Statistical Computing. R Foundation for Statistical Computing, Vienna, Austria.

Rocchini, D., Balkenhol, N., Carter, G.A., Foody, G.M., Gillespie, T.W., He, K.S., Kark, S., Levin, N., Lucas, K., Luoto, M., Nagendra, H., Oldeland, J., Ricotta, C., Southworth, J., Neteler, M., 2010. Remotely sensed spectral heterogeneity as a proxy of species diversity: recent advances and open challenges. Ecol. Inf. 5, 318-329 http://dx.doi.org/10.1016/j.ecoinf.2010.06.001.

Rocchini, D., Hernández-Stefanoni, J.L., He, K.S., 2015. Advancing species diversity estimate by remotely sensed proxies: a conceptual review. Ecol. Inf. 25, 22-28, http://dx.doi.org/10.1016/j.ecoinf.2014.10.006.

Rocchini, D., Boyd, D.S., Féret, J.-B., Foody, G.M., He, K.S., Lausch, A., Nagendra, H., Wegmann, M., Pettorelli, N., 2016. Satellite remote sensing to monitor species diversity: potential and pitfalls. Remote Sens. Ecol. Conserv. 2, 25-36, http:// dx.doi.org/10.1002/rse2.9.

Sekercioğlu, C., Wenny, D.G., Whelan, C.J. (Eds.), 2016. Why Birds Matter: Avian Ecological Function and Ecosystem Services. The University of Chicago Press, Chicago; London.

Salazar, F., Reyes-Bueno, F., Sanmartin, D., Donoso, D.A., 2015. Mapping continental Ecuadorian ant species. Sociobiology 62, http://dx.doi.org/10.13102/ sociobiology.v62i2.132-162.

Schäfer, E., Heiskanen, J., Heikinheimo, V., Pellikka, P., 2016. Mapping tree species diversity of a tropical montane forest by unsupervised clustering of airborne imaging spectroscopy data. Ecol. Indic. 64, 49-58, http://dx.doi.org/10.1016/j. ecolind.2015.12.026.

Schmidtlein, S., Feilhauer, H., Bruelheide, H., 2012. Mapping plant strategy types using remote sensing. J. Veg. Sci. 23, 395-405, http://dx.doi.org/10.1111/j. 1654-1103.2011.01370.x.

Schuldt, A., Assmann, T., Bruelheide, H., Durka, W., Eichenberg, D., Härdtle, W., Kröber, W., Michalski, S.G., Purschke, O., 2014. Functional and phylogenetic diversity of woody plants drive herbivory in a highly diverse forest. New Phytol. 202, 864-873, http://dx.doi.org/10.1111/nph.12695.

Seifert, C.L., Lehner, L., Bodner, F., Fiedler, K., 2016. Caterpillar assemblages on Chusquea bamboos in southern Ecuador: abundance, guild structure, and the influence of host plant quality. Ecol. Entomol. 41, 698-706, http://dx.doi.org/ 10.1111/een.12345.

Sims, D.A., Gamon, J.A., 2002. Relationships between leaf pigment content and spectral reflectance across a wide range of species, leaf structures and developmental stages. Remote Sens. Environ. 81, 337-354, http://dx.doi.org/ 10.1016/S0034-4257(02)00010-X.

Socolar, J.B., Gilroy, J.J., Kunin, W.E., Edwards, D.P., 2016. How should beta-diversity inform biodiversity conservation? Trends Ecol. Evol. 31, 67-80, http://dx.doi.org/10.1016/j.tree.2015.11.005.

Stein, A., Gerstner, K., Kreft, H., 2014. Environmental heterogeneity as a universal driver of species richness across taxa, biomes and spatial scales. Ecol. Lett. 17, 866-880, http://dx.doi.org/10.1111/ele.12277.

Steyn, W.J., Wand, S.J.E., Holcroft, D.M., Jacobs, G., 2002. Anthocyanins in vegetative tissues: a proposed unified function in photoprotection. New Phytol. 155, 349-361, http://dx.doi.org/10.1046/j.1469-8137.2002.00482.x.

St-Louis, V., Pidgeon, A.M., Kuemmerle, T., Sonnenschein, R., Radeloff, V.C., Clayton, M.K., Locke, B.A., Bash, D., Hostert, P., 2014. Modelling avian biodiversity using raw, unclassified satellite imagery. Phil. Trans. R. Soc. 369, 1471-2970 http:// dx.doi.org/10.1098/rstb.2013.0197.

Suessenbach, D., Fiedler, K., 2010a. Pyraloidea species abundance 1999-2000 (species-site matrix). https://doi.org/10.5678/LCRS/PAK823-825.DAT.1546.

Suessenbach, D., Fiedler, K., 2010b. Arctiinae species abundance 1999-2000 (species-site matrix). https://doi.org/10.5678/LCRS/PAK823-825.DAT.1547.

Suessenbach, D., 2003. Diversität von Nachtfaltergemeinschaften entlang eines Höhengradienten in Südecuador (Lepidoptera: Pyraloidea, Arctiidae) (Doctoral thesis). Bayreuth.

Tapia-Armijos, M.F., Homeier, J., Espinosa, C.I., Leuschner, C., de la Cruz, M., 2015. Deforestation and forest fragmentation in South Ecuador since the - losing a hotspot of biodiversity. PLoS One 10, e0133701, http://dx.doi.org/10.1371/ journal.pone.0133701.

Tews, J., Brose, U., Grimm, V., Tielborger, K., Wichmann, M.C., Schwager, M., Jeltsch, F., 2004. Animal species diversity driven by habitat heterogeneity/diversity: the importance of keystone structures. J. Biogeogr. 31, 79-92, http://dx.doi. org/10.1046/j.0305-0270.2003.00994.x.

Thies, B., Meyer, H., Nauss, T., Bendix, J., 2014. Projecting land-use and land-cover changes in a tropical mountain forest of Southern Ecuador. J. Land Use Sci. 9 1-33, http://dx.doi.org/10.1080/1747423X.2012.718378.

Thiollay, J.-M., 1994. Structure, density and rarity in an Amazonian rainforest bird community. J. Trop. Ecol. 10, 449-481, http://dx.doi.org/10.1017/ S0266467400008154.

Tiede, Y., Homeier, J., Cumbicus, N., Peña, J., Albrecht, J., Ziegenhagen, B., Bendix, J., Brandl, R., Farwig, N., 2016a. Phylogenetic niche conservatism does not explain elevational patterns of species richness, phylodiversity and family age of tree assemblages in Andean rainforest. Erdkunde 70, 83-106, http://dx.doi.org/10. 3112/erdkunde.2016.01.06.

Tiede, Y., Schlautmann, J., Donoso, D.A., Wallis, C.I.B., Bendix, J., Brandl, R., Farwig, N., 2016b. Ant abundance as indicator for climate change and predation in megadiverse mountain rainforests in Ecuador. https://doi.org/10.5883/DSSANFRAF.

Tiede, Y., Schlautmann, J., Donoso, D.A., Wallis, C.I.B., Bendix, J., Brandl, R., Farwig, N., 2017. Ant incidence as an indicator of environmental change and ecosystem processes. Ecol. Indic. 83, 527-537 http://ac.els-cdn.com/ S1470160X17300353/dx.doi.org/10.1016/j.ecolind.2017.01.029.

Tuomisto, H., Poulsen, A.D., Ruokolainen, K., Moran, R.C., Quintana, C., Celi, J. Cañas, G., 2003. Linking floristic patterns with soil heterogeneity and satellite imagery in Ecuadorian Amazonia. Ecol. Appl. 13, 352-371, http://dx.doi.org/10. 1890/1051-0761(2003)013[0352:LFPWSH]2.0.CO;2.

Vaglio Laurin, G., Chan, J.C.-W., Chen, Q., Lindsell, J.A., Coomes, D.A., Guerriero, L., Frate, F.D., Miglietta, F., Valentini, R., 2014. Biodiversity mapping in a tropical West African forest with airborne hyperspectral data. PLoS One 9, e97910, http://dx.doi.org/10.1371/journal.pone.0097910.

Wallis, C.I.B., Homeier, J., 2017. Tree species - estimated species diversity 2007-2008. https://doi.org/10.5678/lcrs/pak823-825.dat.1464.

Wallis, C.I.B., Tiede, Y., Donoso, D.A., Brandl, R., Bendix, J., Farwig, N., 2016a. Formicidae species abundance 2014 (species-site matrix). https://doi.org/10. 5678/lcrs/pak823-825.dat.1464.

Wallis, C.I.B., Paulsch, D., Zeilinger, J., Silva, B., Curatola Fernández, G.F., Brandl, R., Farwig, N., Bendix, J., 2016b. Contrasting performance of Lidar and optical texture models in predicting avian diversity in a tropical mountain forest. Remote Sens. Environ. 174, 223-232, http://dx.doi.org/10.1016/j.rse.2015.12 019.

Wang, K., Franklin, S.E., Guo, X., Cattet, M., 2010. Remote sensing of ecology, biodiversity and conservation: a review from the perspective of remote sensing specialists. Sensors 10, 9647-9667, http://dx.doi.org/10.3390/s101109647.

Werner, F.A., Homeier, J., 2015. Is tropical montane forest heterogeneity promoted by a resource-driven feedback cycle? Evidence from nutrient relations, herbivory and litter decomposition along a topographical gradient. Funct. Ecol. 29, 430-440, http://dx.doi.org/10.1111/1365-2435.12351.

Whittaker, R.H., 1972. Evolution and measurement of species diversity. Taxon 21, 213-251, http://dx.doi.org/10.2307/1218190.

Wilson, M.F.J., O’Connell, B., Brown, C., Guinan, J.C., Grehan, A.J., 2007. Multiscale terrain analysis of multibeam Bathymetry data for habitat mapping on the continental slope. Mar. Geod. 30, 3-35, http://dx.doi.org/10.1080/ 01490410701295962.

Wolf, K., Veldkamp, E., Homeier, J., Martinson, G.O., 2011. Nitrogen availability links forest productivity, soil nitrous oxide and nitric oxide fluxes of a tropical montane forest in southern Ecuador. Global Biogeochem. Cycles 25, http://dx. doi.org/10.1029/2010gb003876. 
Wood, E.M., Pidgeon, A.M., Radeloff, V.C., Keuler, N.S., 2012. Image texture as a remotely sensed measure of vegetation structure. Remote Sens. Environ. 121, 516-526, http://dx.doi.org/10.1016/j.rse.2012.01.003.
Wood, E.M., Pidgeon, A.M., Radeloff, V.C., Keuler, N.S., 2013. Image texture predicts avian density and species richness. PLoS One 8, e63211, http://dx.doi.org/10. 1371/journal.pone.0063211.

Zvoleff, A., 2015. glcm: Calculate textures from grey-level co-occurrence matrices (GLCMs) in R. 